\title{
Product packaging communication in the global market - the analysis of consumer behaviour
}

\author{
Barttomiej Kabaja ${ }^{1^{*}}$ \\ ${ }^{1}$ Cracow University of Economics, Department of Packaging Science, Rakowicka St. 27, 31-510 \\ Kraków
}

\begin{abstract}
.
Research background: Business activities of international companies primarily focus on the use of marketing instruments to shape global markets. The basic tactic tools employed are those related to the product and its brand. The changes in lifestyle observed in global society have led to an increase in the importance of packaging and labelling as a means of conveying information from the manufacturer to the consumer.

Purpose of the article: The aim of the study was to analyze consumer behavior related to the selection of canned carbonated drinks offered by various producers, operating on the global and local market. The research material comprised 10 packages of canned carbonated drinks. In terms of the variety of flavors, the products belonged to two different groups: orange-flavored and lemon-flavored.

Methods: Eye tracking was the method used in the study. Eye tracking is a research tool consisting in tracking the visual activity of the examined person. Carbonated drinks evaluations were performed using Tobii X2-30 Eye-tracker. Sixty subjects participated in the test.

Findings \& Value added: The conducted research shows that consumers are more likely to choose the products of global brands than the local ones. In the first part of the study, the respondents focused on graphical elements representing fruit. In the second part, the subjects more often focused on the verbal elements that had been removed from the first part of the test. These findings suggest that verbal elements are very important in the purchasing behavior of consumers.
\end{abstract}

Keywords: packaging, carbonated drinks, global products, local products, brand, eye tracking

JEL Classification: $E 21 ; M 31 ; L 15$

\section{Introduction}

Globalization is a term commonly used today. It impacts various spheres of life, especially the economic, social and cultural activities. The process of globalization is in fact the

${ }^{*}$ Corresponding author: kabajab@uek.krakow.pl 
interplay of these different spheres, moving towards gradual integration of states and communities. The deepening internationalization leads to the introduction of new legal regulations and operational principles of enterprises, as well as affects their competitiveness [1]. According to A. McGrew [2], globalization as a process can be described by several characteristic features:

- overcoming state borders in terms of social, political and economic activities,

- intensification and increase in the importance of mutual connections in almost all spheres of social life,

- $\quad$ increasing pace of development of global interactions and processes,

- $\quad$ an increase in the range, intensity and pace of global interactions connected with the ever-stronger intertwining of what is local with what is global.

The forces influencing and deepening the ongoing process of globalization can be divided into four main groups: economic, political, technological and social. A visual illustration of this idea is presented in Fig. 1.

Globalization in the economic dimension should be understood as the internationalization of enterprises. It is based on the belief that such approach creates opportunities resulting from expanding the scope of activities, which may bring tangible benefits to employers and employees [3].

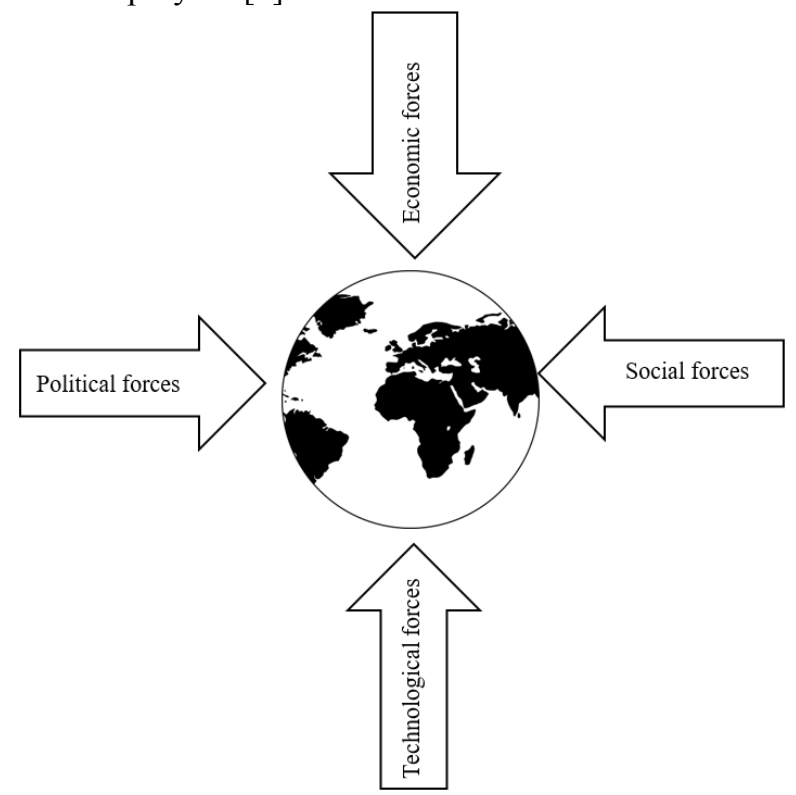

Fig 1. Forces driving the ongoing process of globalization.

The increasingly closer integration of the states within the European Union undoubtedly plays a major role in the globalization of their national economies. The integration and elimination of barriers in business facilitates the intensive development of the consumer products market and influences the emergence of a large number of international companies, offering various types of products and services. Their presence on the market is often supported by intensive advertising campaigns that have a significant impact on consumer behavior [4].

The market success of multinational companies depends primarily on the buyers and consumers of the products and services offered. By focusing the company's activities on satisfying consumer needs, and even creating these needs, an enterprise may achieve the basic strategic goal, which is to acquire customers and meet their needs. Thus, the 
companies are forced to create value whose sum of benefits, in the opinion of potential customers, would be at a higher level than that of their direct competitors.

That is why the role of marketing is so important in the global market [5]. It is not only an economic process, but also social and management one, strongly related to building customer trust and loyalty. The introduction of a global brand is possible if the needs satisfied by a given product are universal. Then, the benefits offered, and the usability of the product, are perceived as identical or very similar in different countries. What is more, the benefits of introducing a global brand basically mean greater effectiveness of international promotional activities [6-7]. Through coordinated and uniform efforts, a strong international brand image is created. It is characterized by global recognition and prestige, which gives the opportunity to achieve economies of scale.

Due to the fact that the vast majority of products are sold in a packaged form, the role of shaping the image and stimulating product sales is realized through the product packaging [8]. Through its shape, size, color and construction form, packaging communicates value to consumers. The role of packaging in this process has been increasing, particularly since the development of self-service sales. Information addressed to consumers using the packaging may have a denoting meaning (determining that a given product belongs to a certain product group, e.g. it is a drink) or connotative (differentiating a product within a given product category, e.g. an orange-flavored drink from other drinks) [9].

According to R. Kuvykaite et al. [10], visual and verbal features are important elements of packaging, influencing consumer choices. The visual elements include graphics, color, size, shape, and material; whereas verbal elements are product information, manufacturer name, country of origin and brand. Activities related to building the marketing strategy of the product on global markets focus on the scope of the product standardization and adaptation. Due to the adopted purpose of the study and the character of the combination of the product and packaging, which makes both of these elements inherently connected with each other [11], the standardization and adaptation strategy is discussed in relation to the packaging of consumer products.

The aim of the study was to analyze consumer behavior related to the selection of canned carbonated drinks offered by various producers, operating on the global and local market. In order to obtain more specific data, the eye tracking method was employed in the research.

\section{Methodology}

The research material comprised 10 packages of canned carbonated drinks. In terms of the variety of flavors, the products belonged to two different groups: orange-flavored and lemon-flavored. The study included products offered by companies such as: The Coca-Cola Company, PepsiCo Inc., Rauch Fruchtsäfte, Arizona, Terme di Crodo, Dr Pepper Snapple Group and Hermann Pfanner Getränke. Some of these brands operate globally using product standardization strategies (e.g. The Coca-Cola Company, PepsiCo Inc). Others, in turn, operate locally. Carbonated drinks were chosen for the research material because of their general popularity. According to Grand View Research reports [12], the market of these products is constantly growing. Moreover, these products are widely and easily available to consumers regardless of their age, gender and place of residence [13-15]. Carbonated drinks also meet the assumptions of global products, i.e. they should be present on many markets, satisfy the same consumer needs, have a relatively uniform quality, etc.

Additionally, the eye tracking method was employed in the research. It involves the use of eye movement analysis in the perception of visual objects while following the test scenario [16]. When recording an image, the eye performs two types of movements: fixations and saccades. On this basis, the analysis of the activity of the eyeballs is used in 
research [17]. The effectiveness and usefulness of scientific research related to product packaging using eye tracking has been confirmed by a number of studies [18-22]. Yet, the application of this method is not common in the literature, mainly due to the complexity of the specialized equipment and the high cost of the test.

The adopted research procedure consisted in the respondents' assessing the packaging of two flavor groups of canned carbonated drinks. The assessment included matching the graphic design of the packaging to the taste of the drink, and the product selection in the event of a possible purchase. In the first part of the study, the respondents were shown the product packaging with no verbal elements, in accordance with the procedure proposed by R. Kuvykaite et al. [10]. Thus, the packages were presented without visible letters, words, names, etc. The adopted research procedure is shown in Fig. 2.

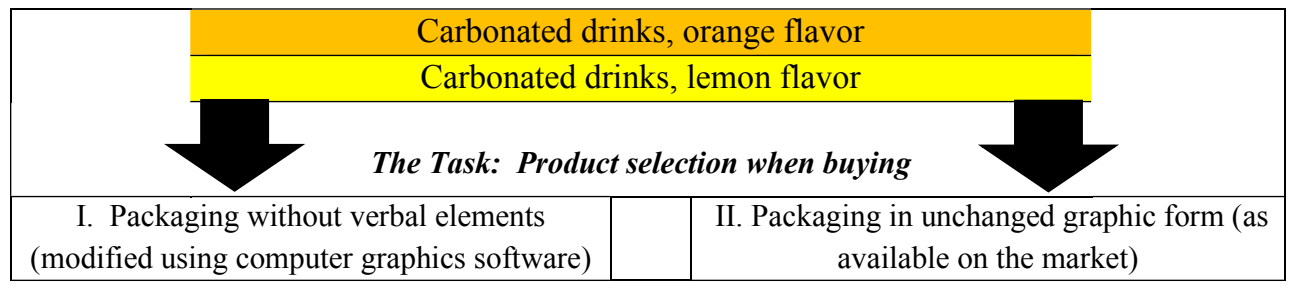

Fig. 2. Research procedure for carbonated drinks.

The selection of respondents in the conducted study was random. Sixty subjects participated in the test. The survey was conducted in Poland, among citizens of that country. The detailed structure of the studied population is presented in Table 1.

Table 1. Socio-demographic characteristics of the examined population.

\begin{tabular}{|c|c|c|c|}
\hline \multirow{2}{*}{ Independent variables } & \multirow{2}{*}{ Segment } & \multicolumn{2}{|c|}{$\begin{array}{c}\text { Examined } \\
\text { population } n=60\end{array}$} \\
\hline & & $\mathbf{n}$ & $\%$ \\
\hline \multirow[t]{2}{*}{ Gender } & female & 27 & 45 \\
\hline & male & 33 & 55 \\
\hline \multirow[t]{3}{*}{ Age [years] } & below 19 & 4 & 7 \\
\hline & $20-40$ & 55 & 92 \\
\hline & above 40 & 1 & 1 \\
\hline \multirow[t]{3}{*}{ Education } & Secondary or lower & 26 & 43 \\
\hline & $\begin{array}{l}\begin{array}{l}\text { Undergraduate level (Bachelor's } \\
\text { degree or equivalent) }\end{array} \\
\end{array}$ & 16 & 27 \\
\hline & $\begin{array}{l}\text { Graduate level (Master's degree or } \\
\text { equivalent) }\end{array}$ & 18 & 30 \\
\hline \multirow{3}{*}{ Place of residence } & Rural area & 23 & 38 \\
\hline & Town up to $100 \mathrm{k}$ inhabitants & 8 & 14 \\
\hline & Town above $100 \mathrm{k}$ inhabitants & 29 & 48 \\
\hline
\end{tabular}


In terms of gender, 27 women and 33 men participated in the study; whereas in terms of age, the largest group were people aged 20-40 (92\%). Furthermore, the majority of respondents came from towns above 100 thousand inhabitants $(48 \%)$, followed by the residents of rural areas $(38 \%)$.

\section{Results}

The results of individual consumer choices regarding the purchase of a carbonated drink are presented in Figures 3 to 4 . The selection of carbonated drinks with no verbal elements exhibited on the packaging are marked blue, and the selection of products shown to respondents in an unchanged graphic form are given in orange.

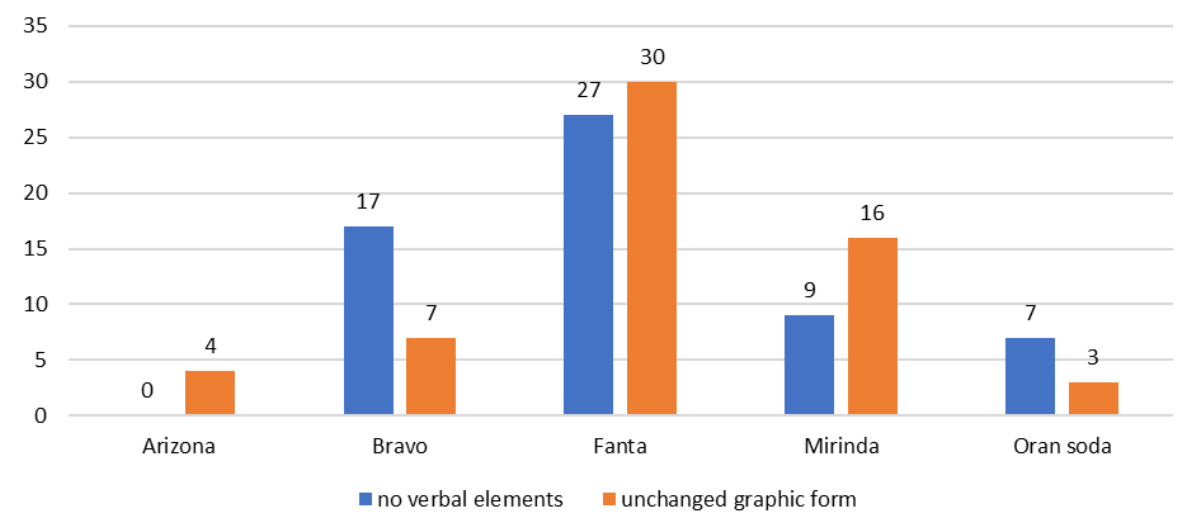

Fig. 3. Product selection results for orange-flavored carbonated drinks.

When the orange-flavored drinks were tested (Fig. 3), it can be seen that global brand products such as Fanta and Mirinda obtained better results when their packaging was presented in an unchanged graphic form. On the other hand, Bravo and Oran Soda products had more indications when exhibited without verbal elements.

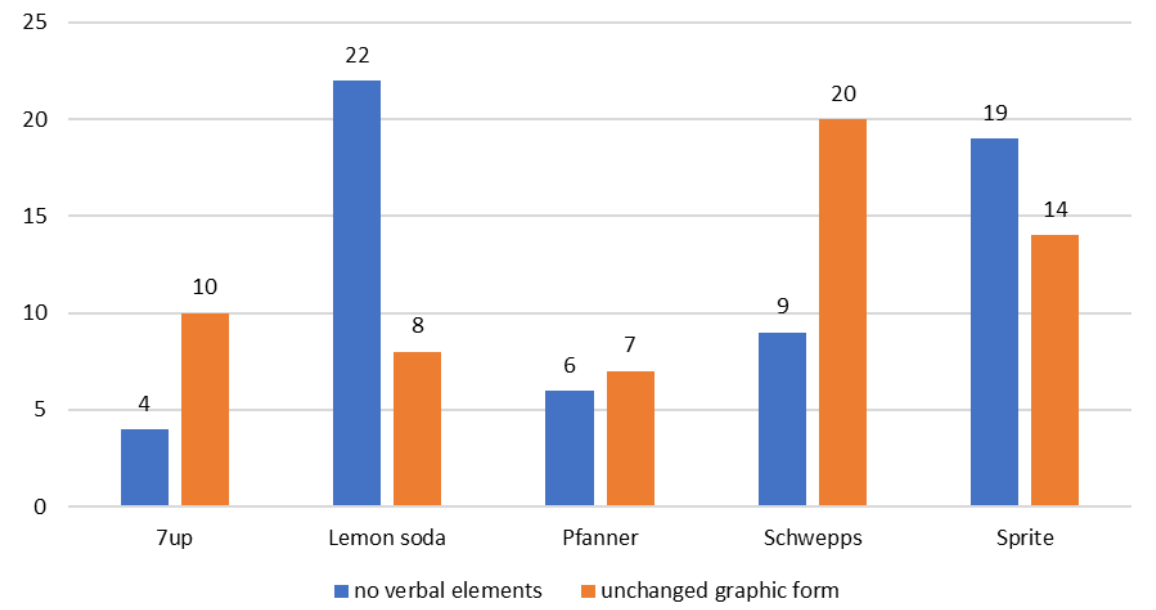

Fig. 4. Product selection results for lemon-flavored carbonated drinks. 
In the lemon-flavored soft drinks test (Fig. 4), it can also be observed that the less known local brands obtained better selection scores compared to other products when the verbal elements were removed from the packaging. In turn, when selecting from among the products with the standard graphic form of the packaging, many respondents changed their minds and indicated global brands, such as 7up or Schwepps. An exception was the packaging of Sprite, which received more indications of consumer choice when it was shown with no verbal elements. It is also worth mentioning the findings concerning Lemon Soda, whose packaging when shown in its full graphic form lost as many as 14 potential buyers.

As can be observed in the figures above, consumer choices vary depending on whether there are verbal elements on a given packaging. Hence, it may be inferred that verbal elements or their absence on the packaging have a significant impact on consumer attitudes, especially when it comes to purchasing a product.

In order to determine which elements of the packaging the respondents paid most attention to, the heat maps for each group of products tested was elaborated [23-24]. Heat maps are graphic forms of presenting data collected during the eye tracking test. By using colors - from warm red to cool green - they reflect the time the subjects looked at a given area. The red spots show the areas where the participants of the study looked the longest (the most frequently).

The data obtained from the eye tracking tests are presented in Fig. 5-8. To facilitate the comparison, in each case, the heat map was matched with the graphic forms presented to the respondents. The areas marked in red show the places with the most intensive eye fixations.

As can be seen from the heat maps (Figs. 5 and 6) created on the basis of data collected from the part of the test when the packaging was shown to respondents without verbal elements, while getting to know the packaging, consumers paid the greatest attention to the graphical elements presenting an orange fruit or a lemon fruit.

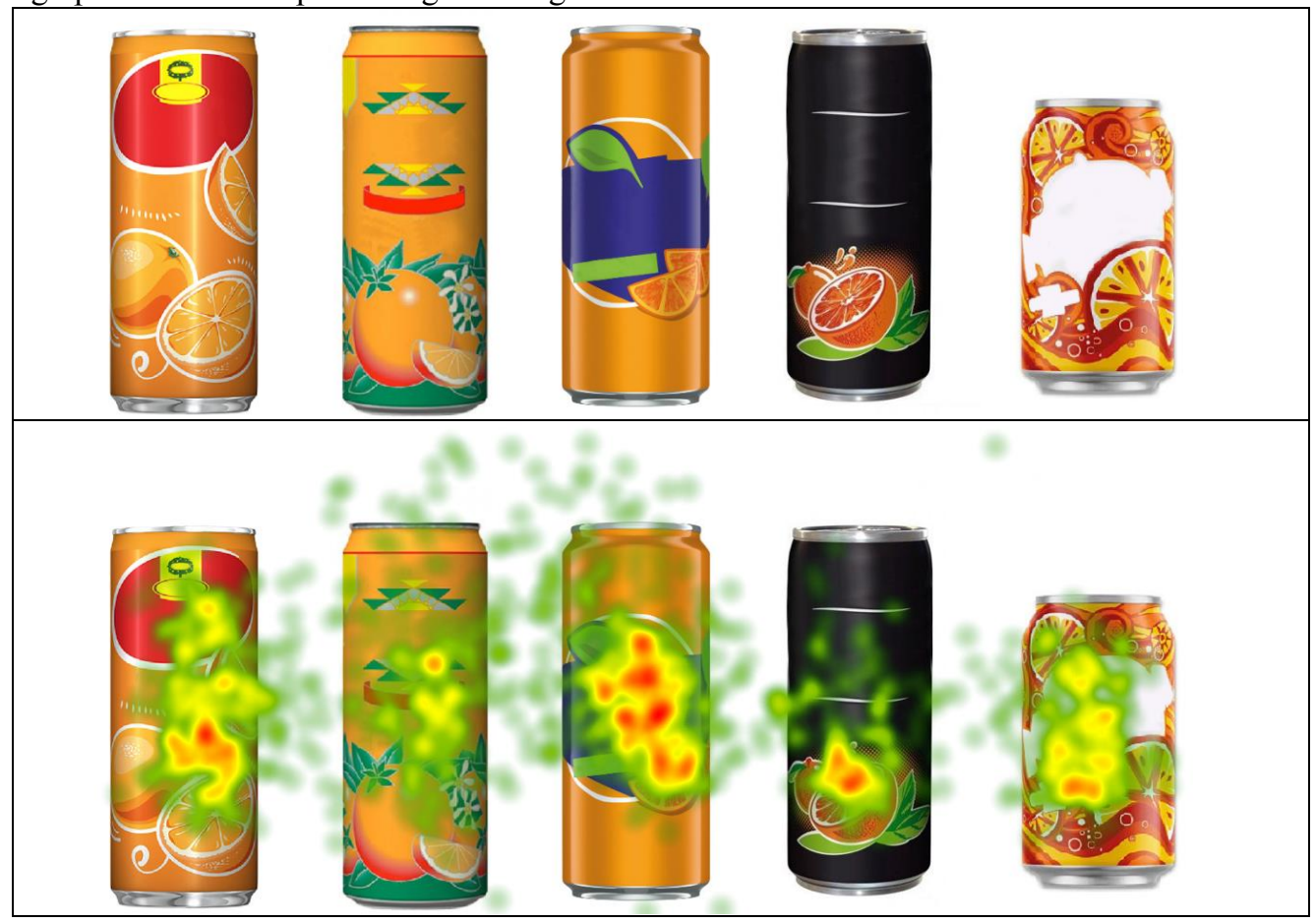

Fig. 5. Heat maps - orange-flavored carbonated drinks with no verbal elements. 


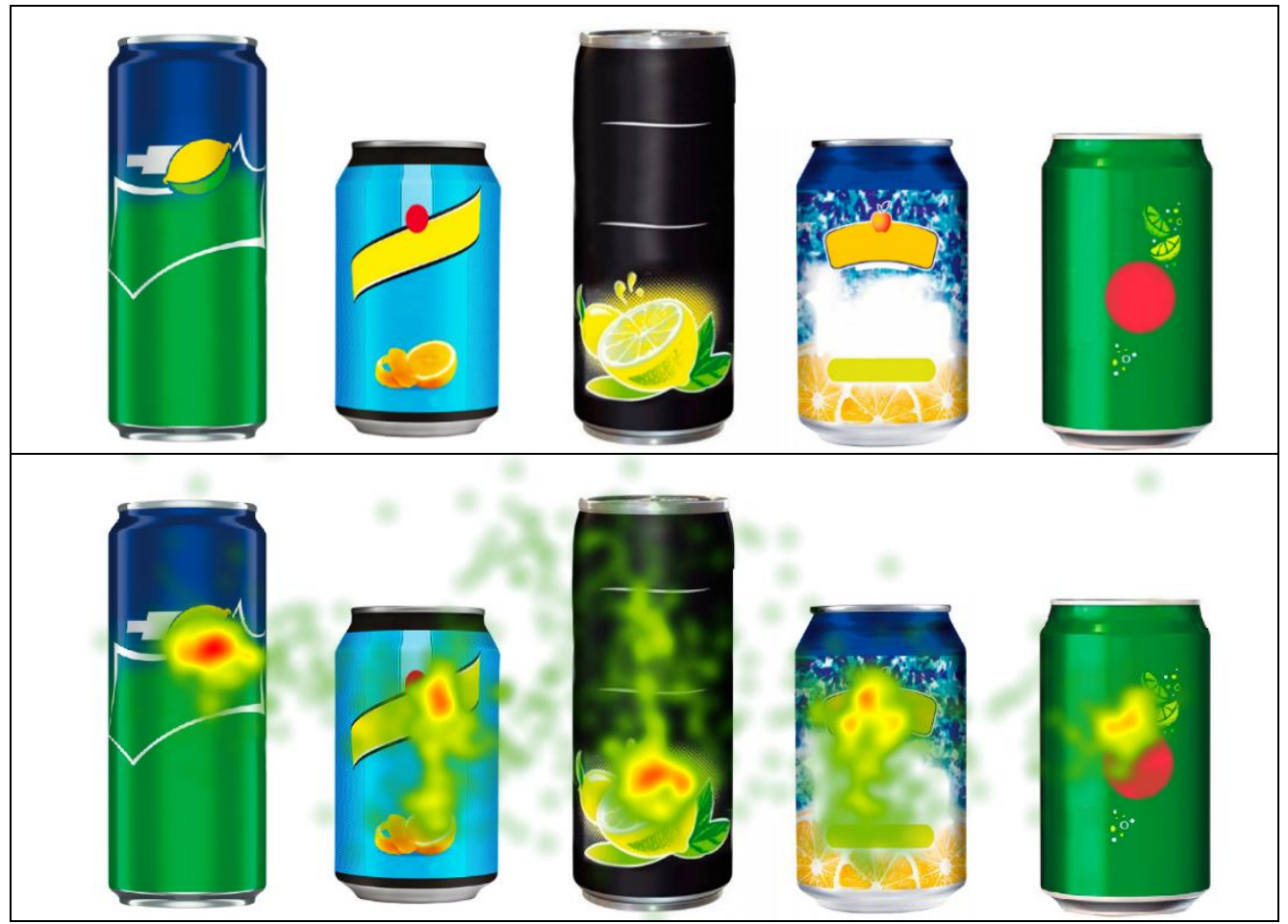

Fig. 6. Heat maps - lemon-flavored carbonated drinks with no verbal elements.

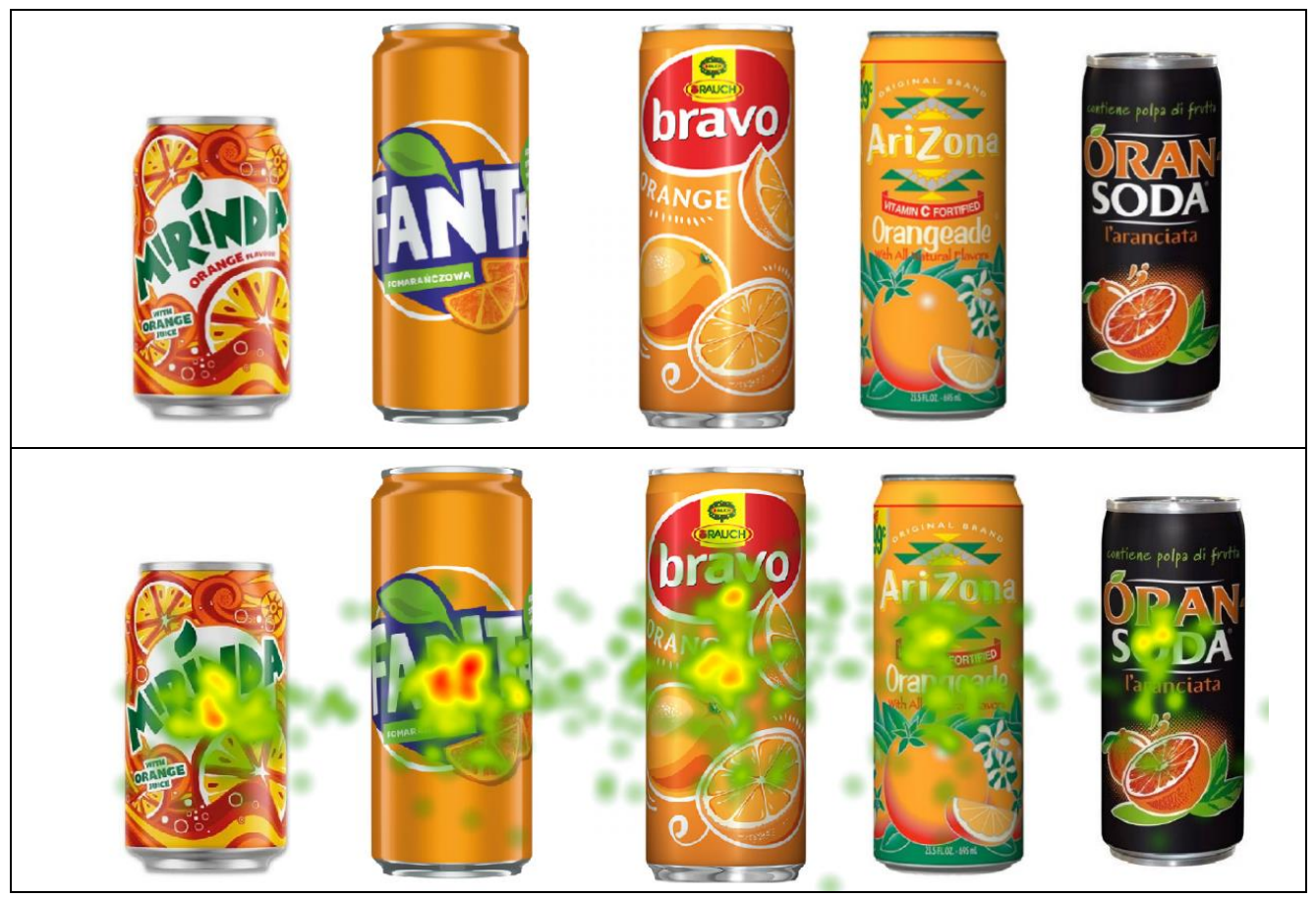

Fig. 7. Heat maps - orange-flavored carbonated drinks with unchanged graphic form. 
Figures 7-8 show the heat maps obtained during the second part of the eye tracking study. Consumers could then make their choice of a drink by being provided with the full market version of the product packaging. As in the case of the first part of the study, the obtained heat maps were compared with the forms of product packaging presented to the respondents. The heat maps show that in this part of the study consumers most frequently looked at product names, brand, and other alphabetic characters (verbal cues). This is confirmed by the red areas on the heat maps. Compared to the first part of the test, the respondents looked at graphics depicting fruit or any other elements suggestive of flavor much less frequently or not at all.

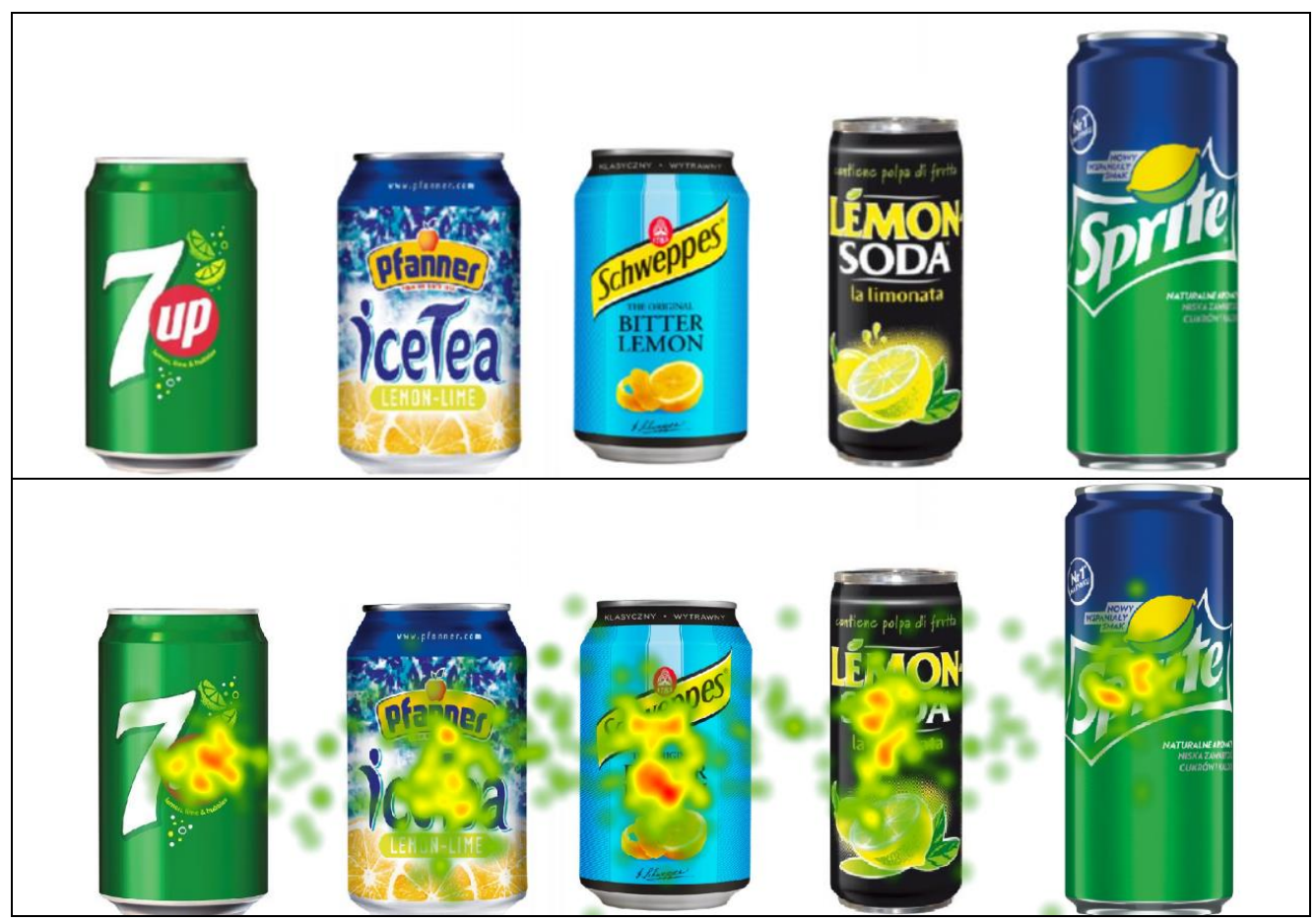

Fig. 8. Heat maps - lemon-flavored carbonated drinks with unchanged graphic form.

\section{Discussion and Conclusion}

On the basis of the study results, the behavior of consumers when choosing carbonated drinks in cans may be determined. The study analyzes two groups of beverages depending on their flavor: orange and lemon. The study findings suggest that the presence of verbal elements influences consumer behavior in terms of beverage choice. Consumers most often declared the choice of beverages belonging to global brands, whereas the products of local brands obtained fewer indications. The survey was conducted among Polish citizens only, which may be an obvious limitation. Therefore, it is suggested to include a more diverse group of respondents in terms of nationality when conducting further research. In terms of global brands (Fanta, Mirinda,7up, Schwepps), an increase in product selection indications was observed in the second part of the study (when the product packaging was presented with unchanged graphic form). It is worth noting that in the case of Sprite, a decrease in the number of product indications was observed. When the product packaging of this brand was presented to respondents without verbal elements, it obtained more indications than when the full graphic form was given. 
The analysis of the frequency of eye fixations on individual packages and their elements during the study allowed to determine the areas of packaging in which consumers were most interested in the first and second part of the study. In the first part, the respondents focused on graphical elements presenting fruit. In the second part of the study, the subjects more often focused on the verbal elements that had been removed from the first part of the test. These findings suggest that verbal elements are very important in the purchasing behavior of consumers.

The conducted research shows that consumers are undoubtedly more likely to choose the products of global brands than the local ones. The consumer choices are influenced by various factors; however, in this study the same conditions were maintained and the only feature differentiating the respondent choices was the presence or absence of verbal elements. Moreover, the eye tracking test showed that verbal elements on the packaging play a crucial role when selecting a product and making purchase decisions.

"The Project has been financed by the Ministry of Science and Higher Education within "Regional Initiative of Excellence" Programme for 2019-2022. Project no.: 021/RID/2018/19. Total financing: 11897 131,40 PLN

\section{References}

1. Dębicka, O., Oniszczuk-Jastrząbek, A. (2019). Przedsiębiorstwo w otoczeniu globalnym. Wybrane zagadnienia. Gdańsk: Wydawnictwo Uniwersytetu Gdańskiego.

2. McGrew, A. (2008). Globalizacja i polityka globalna, In J. Baylis i S. Smith (Eds.), Globalizacja polityki światowej. Wprowadzenie do stosunków międzynarodowych (pp. 114-125). Kraków: Wydawnictwo Uniwersytetu Jagiellońskiego.

3. Rymarczyk, J. (2004). Internacjonalizacja i globalizacja przedsiębiorstwa. Warszawa: PWE.

4. Smyczek, S. (2009). Współczesny marketing wobec problemów globalizacji gospodarki. Katowice: Wyższa Szkoła Zarządzania Marketingowego i Języków Obcych w Katowicach.

5. Gallino, S., Rooderkerk, R. (2020). New product development in an omnichannel world. California Management Review, 63(1), 81-98.

6. Hoskins, J., Verhaal, J. C., Griffin, A. (2020). How within-country consumer product (or brand) localness and supporting marketing tactics influence sales performance. European Journal of Marketing, fortcoming article.

7. Salnikova, E., Grunert, K. G. (2020). The role of consumption orientation in consumer food preferences in emerging markets, Journal of Business Research, 112, 147-159.

8. Martin, C., Lange, C., Marette, S. (2021). Importance of additional information, as a complement to information coming from packaging, to promote meat substitutes: A case study on a sausage based on vegetable proteins. Food Quality and Preference, 87, 104058.

9. Szymczak, J., Ankiel-Homa, M. (2007). Opakowanie jednostkowe $w$ działaniach marketingowych przedsiębiorstw. Poznań: Wydawnictwo Akademii Ekonomicznej w Poznaniu.

10. Kuvykaite, R., Dovaliene, A., Navickiene, L. (2009). Impact of packaging elements on comsumer's purchase decision, Economics \& Management, 14, 441-447. 
11. Lisińska-Kuśnierz, M., Ucherek, M. (2006). Opakowania w ochronie konsumenta. Kraków : Wydawnictwo Akademii Ekonomicznej w Krakowie.

12. Grand View Research. (2020, September). Carbonated beverages market size, share \& trends analysis report by product (Soft Drinks, Sports \& Energy Drinks), by flavor (Cola, Fruit Based), by distribution channel, by region, and segment forecasts, $2020-$ 2027. https://www.grandviewresearch.com/industry-analysis/carbonated-beveragesmarket

13. Sylvetsky, A. C., Visek, A. J., Halberg, S., Rhee, D.K., Ongaro, Z., Essel, K. D., Dietz, W. H., Sacheck, J. (2020). Beyond taste and easy access: Physical, cognitive, interpersonal, and emotional reasons for sugary drink consumption among children and adolescents, Appetite, 155, 104826.

14. Jung, H., Dan, H., Pang, Y., Kim, B., Jeong, H., Lee, J. E., Kim, O. (2020). Association between dietary habits, shift work, and the metabolic syndrome: the Korea Nurses'Health study, International Journal of Environmental Research and Public Health, 17(20), 7697.

15. Munoz, V. C., Rovira, M. U., Ibanez, V. V., Dominguez, J.M. M., Blanco, G. R., Rovira, M. U., Toran, P. (2020). Consumption of soft, sports, and energy drinks in adolescents. The BEENIS study, Anales de pediatria, 93(4), 242-250.

16. Milic-Czerniak, R. (2019). Badania marketingowe. Nowo metody badań $i$ zastosowania. Warszawa: Difin SA.

17. Duchowski, A. (2003). Eye Tracking Methodology. Theory and Practice. London: Springer Verlag.

18. Cholewa-Wójcik, A., Świda, J. (2015). A study and assessment of selected elements of the visual aspects of collectible chocolate packaging with the use of the eye-tracking method, Indian Journal of Marketing, 45(7), 7-18.

19. Kabaja, B. (2018). Kryteria oceny znakowania opakowań jednostkowych suplementów diety. Kraków: Prace Doktorskie, Wydawnictwo Uniwersytetu Ekonomicznego w Krakwoie.

20. Kim, M. A., Yoo, H. J., Ares, G., Lee, H. S. (2020). Effect of thinking style and consumption purpose on food choice: A case study with yogurt using a discrete choice experiment and eye-tracking, Food Quality and Preference, 86, 104025.

21. Lacoste-Badie, S., Yu, J.W., Droulers, O. (2020). Small change, big change Increasing attention with product package variations. Food Quality and Preference, 86, 104007.

22. Totzek, D., Jurgensen, G. (2020). Many a little makes a mickle: Why do consumers negatively react to sequential price disclosure? Psychology \&Marketing, fortcoming article.

23. Bojko, A. (2013). Eye Tracking the User Experience: A Practical Guide to Research, New York : Rosenfeld Media.

24. Mościchowska, I., Rogoś-Turek, B. (2015). Badania jako podstawa projektowania User Experience. Warszawa: Wydawnictwo Naukowe PWN. 